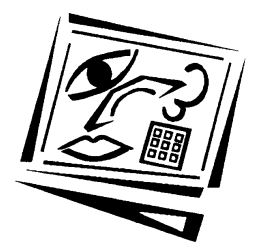

\title{
Students' perceptions of using Facebook as an interactive learning resource at university
}

\author{
Christopher Irwin, Lauren Ball and Ben Desbrow \\ Griffith University \\ Michael Leveritt \\ The University of Queensland
}

\begin{abstract}
Facebook is a popular platform that may facilitate learning activities at university. In this study, students' perceptions of using 'Facebook pages' within individual university subject offerings were evaluated. Individual 'Facebook pages' were developed for four university courses and used to provide information relevant to the courses and allow opportunities for student interaction. An initial questionnaire administered in the first lecture of semester indicated that nearly all students $(n=161,93.1 \%)$ possessed an active Facebook account. Most students $(n=135,78.0 \%)$ anticipated that a Facebook page would facilitate their learning, by increased interaction with students and instructors, and notifications for course information. A second questionnaire was completed in the final lecture of semester indicating that $81.9 \%$ of students engaged with the course Facebook page at some stage. However, perceptions of the effectiveness of the page as a learning tool were variable, with only $51 \%$ of students stating that it was effective. Despite this, the majority of students $(n=110,76.4 \%)$ recommended using Facebook in future courses. This preliminary evaluation of Facebook as a learning aid suggests that it has the potential to promote collaborative and cooperative learning, but further research is required, specifically to understand if and how it can enhance learning outcomes.
\end{abstract}

\section{Introduction}

Blended learning, integrating a variety of media to deliver teaching material to students is increasingly prevalent in university education. Blended learning is often associated with the use of web tools such as email, lecture recordings, blogs, discussion boards, and a dedicated university learning management system (e.g. Blackboard). Institutional based learning management systems are being used by universities all over the world. These systems are often designed to provide a web presence for course instruction and assist with the organisation and management of course material (Coates, James \& Baldwin, 2005). Typically, they propose to offer an environment that helps to engage students and enrich the quality of the student experience through interactive learning activities. In general, they are designed to support the development, management, and delivery of blended learning.

However, there are some suggestions that whilst learning management systems are well developed to manage processes such as student enrolment, exams, assignments, course descriptions, lesson plans, messages, syllabus, and basic course material, they are not well suited to self-governed and problem-based learning activities (Dalsgaard, 
2006). In addition, these programs often lack an element of social connectivity and the personal profile spaces which today's students are familiar with (Mazman \& Usluel, 2010). The emergence of social networking software and popular networking sites such as Facebook have raised questions regarding the value of course integrated learning management systems. Social networks have the potential to offer better support for self-governed, problem-based and collaborative learning processes (Dalsgaard, 2006).

Facebook is a website that allows users to interact and collaborate within a pre-defined virtual community. Often termed a social networking site, Facebook is an online communication tool allowing users to construct a public or private profile in order to connect and interact with people who are part of their extended social network (Boyd \& Ellison, 2007). The majority of undergraduate students at university or college use Facebook on a daily basis (Hewitt \& Forte, 2006; Kirschner \& Karpinski, 2010; Madge, Meek, Wellens \& Hooley, 2009; Ophus \& Abbitt, 2009; Roblyer, McDaniel, Webb, Herman \& Witty, 2010; Santos, Hammond, Durli \& Chou, 2009; Subrahmanyam, Reich, Waechter \& Espinoza, 2008; Wise, Skues \& Williams, 2011; Wolfe, 2007). Whilst there are some reports that students use Facebook instinctively to support both their academic and social goals (Bosch, 2009; Madge et al., 2009; Mazman \& Usluel, 2010; Tian, Yu, Vogel \& Kwok, 2011), the majority of evidence suggests that students' main motive for using Facebook is for social connectivity (Bosch, 2009; Madge et al., 2009; Mazman \& Usluel, 2010; Ophus \& Abbitt, 2009; Roblyer et al., 2010; Subrahmanyam et al., 2008; Wise et al., 2011). A recent study by Wise et al. (2011) examining Facebook use by first year psychology students found that students spent an average of one hour per day on the site, but that use was predominately to engage in social interactions. Only a small proportion of the student sample (4.9\% of 390 students surveyed) reported that Facebook provided them with information, and the authors suggested that Facebook has a limited role in supporting student academic engagement.

Since its introduction in 2004, Facebook has rapidly become the most popular social networking site in the world (Mazman \& Usluel, 2010), with reports of more than 750 million active users worldwide (according to Facebook.com statistics retrieved in August, 2011). Despite being known primarily for social networking activity, Facebook is quickly being recognised as a respectable e-learning platform (Bosch, 2009). Compared with traditional university course sites, students are more engaged with Facebook. In addition, some studies suggest that students are receptive to the possibilities of integrating Facebook into university courses, with the potential for learning benefits associated with increased communication among students, greater access to course materials, and improved logistical management of courses (Bosch, 2009; Madge et al., 2009; Ophus \& Abbitt, 2009).

Social networking sites engage students in online learning communities using technologies familiar to and accepted by their generation (Oradini \& Saunders, 2008). Incorporation of this pedagogical strategy could offer new opportunities to enhance academic instruction and student learning experiences (Ouf, Nasr, \& Helmy, 2010). For example, Facebook has the capacity to support course management activities, enhance the provision of information and resources to students, as well as engage and motivate students through interactivity and collaboration (Naidu, 2005). Using Facebook as a host site to incorporate assessment, McCarthy (2010) reported positive student feedback for its integration into the learning environment. Students in this study noted many advantages of the online learning environment and Facebook tasks. Reports of improved academic relationships being developed between both domestic and international student groups, the generation of rewarding academic discussions that 
were beneficial for study, and increased interaction with the peer group were among the main findings. In a more recent study, McCarthy (2012) explored the use of Facebook as an alternative to traditional face to face mentoring of undergraduate and postgraduate students across internationally separated universities. Reports of the student experience from the mentoring scheme were positive from both international partners. Students believed Facebook was a valuable resource as an academic tool, improving the development of academic connections and promoting academic critiques, discussion and networking to enhance the learning experience. Rambe (2012) also noted that Facebook benefited students by promoting visibility of common problems that students had with course based concepts, whilst allowing academics to more easily recognise challenges students were experiencing with the course.

The use of Facebook as a learning environment in higher education is not without potential risks and limitations. Questions regarding content ownership, privacy, stalking and cyberbullying, and virtual integrity are often issues that require consideration (Cluett, 2010; McCarthy, 2012 ; Willems \& Bateman, 2011). In addition, concerns about Facebook as a form of distraction (Wise et al., 2011) and the influence it has on academic performance (Kirschner \& Karpinski, 2010) have been raised. Most studies examining Facebook in a university context have focused on students' use of the web application and its subsequent impact on study time. Conflicting evidence exists on the impact of Facebook on dedicated study time with some authors suggesting that Facebook users spend less time studying and achieve lower academic results compared to Facebook non-users (Kirschner \& Karpinski, 2010), whereas other authors have not found this association (Kabre \& Brown, 2011). However, the limitation of these studies is that they have explored the impact of Facebook on individual academic performance, independent of its potential to provide other educational benefits to students. Student satisfaction with university education is becoming ever more important, and studies have shown that student satisfaction has a positive impact on student motivation and retention, amongst other institutional benefits (Elliott \& Shin, 2002). Incorporation of Facebook into the learning resources of university courses may impact upon student satisfaction of course delivery, as they are able to integrate academic requirements with a social networking platform that they are familiar and highly engaged with.

University education is student focused and it is therefore important to consider students' perceptions of technology that is integrated into their learning environment. The aim of this study was to evaluate student perceptions of using a designated 'Facebook page' as a learning resource within university courses. It was hypothesised that 'Facebook pages' associated with university courses would be widely utilised by enrolled students, lead to greater communication between students, and enhance student's interaction with the course instructor and associated learning resources.

\section{Method}

\section{Participants}

The study was conducted at Griffith University's Gold Coast campus during the second teaching semester of the 2011 academic year. The sample was one of convenience involving instructors $(n=4)$ and students $(n=253)$ from four courses conducted by the University's Health faculty. The total sample group included two undergraduate courses (class $1=67$ students and class $2=143$ students, total $n=210$ ), and one postgraduate course $(n=32)$ offered by the School of Public Health. Approval 
for the study was granted by the Human Research Ethics Committee of Griffith University (PBH/28/11/HREC).

\section{Course Facebook pages}

At the beginning of the semester, individual Facebook pages were developed by the instructor in each of the courses involved in the study. In the first lecture for each course, students were informed of the course Facebook page and instructed that they could use it as a learning resource throughout the semester by visiting the page and clicking on the 'Like' button. When this was done, a connection was made between the course page and the student's personal Facebook account. The course page would then appear in the 'Activities and Interests' section of the student's profile, and allowed publication of updates and notifications to the student, which would appear in the 'News Link' of the student's personal Facebook page. Student engagement with the course Facebook page was strongly encouraged by the course instructors; however there was no formal assessment or incentive associated with students' participation.

The Facebook pages were used as a platform to provide information relevant to the courses and to allow opportunities for student networking to occur. Each instructor posted on the course Facebook page approximately 3-5 times each week during semester. The posts included notifications for available course material such as lecture notes, tutorial sheets, or changes to lecture times and locations, reminders for assessment items, links to useful and interesting media and learning materials related to the course, and topics provided by instructors to create discussion amongst students. Posts were visible on the Facebook page 'wall' to all individuals who had 'Liked' the course Facebook page. Students were able to comment on any post on the Facebook page 'wall', as well as post their own questions regarding course material or administrative-based queries. Course instructors logged on to the course Facebook page at least once per day to respond to questions and monitor discussions. Discussions were monitored to ensure that content was appropriate to the course material, maintained academic integrity, and abided by University's Code of Conduct and Information Technology policy.

Learning materials were available to students via the University's online teaching and blended learning environment 'Learning@Griffith' which uses the Blackboard course management software. Students who received notifications via the course Facebook page were still required to access the material from the dedicated Learning@Griffith course site.

\section{Questionnaires}

To examine students' interaction with the course Facebook pages, as well as perceptions of its utility as a learning resource, data was gathered via two paper-based questionnaires. The initial questionnaire was administered in the first lecture of semester (pre-semester questionnaire) while the second questionnaire was completed during the final lecture of semester (post-semester questionnaire) for each course. A copy of each questionnaire was provided to all students attending the lecture, which they were asked to complete anonymously and return to the instructor at the end of the session.

The initial questionnaire consisted of six items. Questions included previous Facebook use and/or preparedness to create an account in order to participate in course Facebook 
activities. Students were also initially asked to consider Facebook's capacity to facilitate their learning during the semester, their expectations of the course Facebook page, and the utility of Facebook as a learning resource. The final questionnaire consisted of 8 items and focused on the students' use of the course Facebook page, their perceptions of its usefulness, suggestions for improvement, and ultimately their perspective on its future as a student support tool.

\section{Data analysis}

All analyses were conducted using the IBM SPSS statistical software package version 19.0 (SPSS, 2010). Frequency distributions were calculated for each item from the presemester and post-semester questionnaires. Pearson's chi-square test was used to compare undergraduate and postgraduate responses regarding the use of the course Facebook page as an effective learning tool. Statistical significance level was set at $p<0.05$. Open ended comments were grouped into categories and direct quotes were included in the results to support findings.

\section{Results}

\section{Pre-semester student perceptions}

A total of 173 students (response rate $=68.4 \%$ ) completed the pre-semester questionnaire, including 137 (response rate $=65.2 \%$ ) undergraduate students and 36 (response rate $=83.7 \%)$ postgraduate students. Nearly all students $(n=161,93.1 \%)$ possessed an active Facebook account. Of the few students who did not have a current account, $(n=12,6.9 \%), 6$ students $(50 \%)$ were prepared to create an account in order to participate in course Facebook activities.

Most of the students $(n=135,78.0 \%)$ anticipated that a course Facebook page would facilitate their learning during the semester. The proposed methods by which the Facebook page could facilitate student learning are listed in Table 1.

Table 1: Methods anticipated by students as contributing to learning through the course Facebook page $(n=135)$

\begin{tabular}{|l|c|}
\hline $\begin{array}{l}\text { Statement: How will a course Facebook page facilitate your learning this } \\
\text { semester?* }\end{array}$ & $\begin{array}{c}\text { No. of } \\
\text { responses (\%) }\end{array}$ \\
\hline Increased interaction with course convenor and fellow students & $109(80.8)$ \\
\hline Participation in general discussion about course topics & $108(80.0)$ \\
\hline Notifications for lecture note availability, and assessment items & $102(75.6)$ \\
\hline Exposure to relevant media and learning materials & $76(56.3)$ \\
\hline
\end{tabular}

Students also provided open comments regarding their perceptions on the use of a course Facebook page for the commencing semester. These comments were grouped into two contrasting categories. One belief was that students anticipated that the integration of a course Facebook page would enhance the quantity of information passed from instructors to students and facilitate interaction between fellow students regarding course content.

Great idea and allows much quicker and convenient access to needed materials and/or information (Undergraduate student, 3rd year course). 
This is a good idea, allowing interaction with other students (Undergraduate student, 1st year course).

Alternatively, some concern was raised about the need to keep up to date with the course Facebook activity in addition to other communication media such as emails and the 'Learning@Griffith' discussion boards.

Just something else to remember to check. Is discussion board enough?

(Undergraduate student, 1st year course).

Learning@Griffith allows PDF, video, lecture capture, email correspondence. I would question the need for an additional communication medium (Undergraduate student, 3rd year course).

\section{Post-semester student perceptions}

A total of 144 students completed the post-semester questionnaire (response rate $=$ $56.9 \%$ ), including 115 (response rate $=54.8 \%$ ) undergraduate students and 29 (response rate $=67.4 \%$ ) postgraduate students. Of the 12 students who did not possess a Facebook account at the beginning of semester, 5 students created a Facebook account in order to participate in course Facebook activities.

Overall, $81.9 \%$ of students engaged with the course Facebook page at some stage throughout the semester. The majority of students at the least viewed $(80.5 \%)$, or 'Liked' $(74.6 \%)$ the page, whilst fewer students actually added comments $(38.1 \%)$ or used the page as a way to contact the course instructors $(19.5 \%)$ or other students $(21.2 \%)$. Students were inclined to engage with the course Facebook page at least once each week (Figure 1).

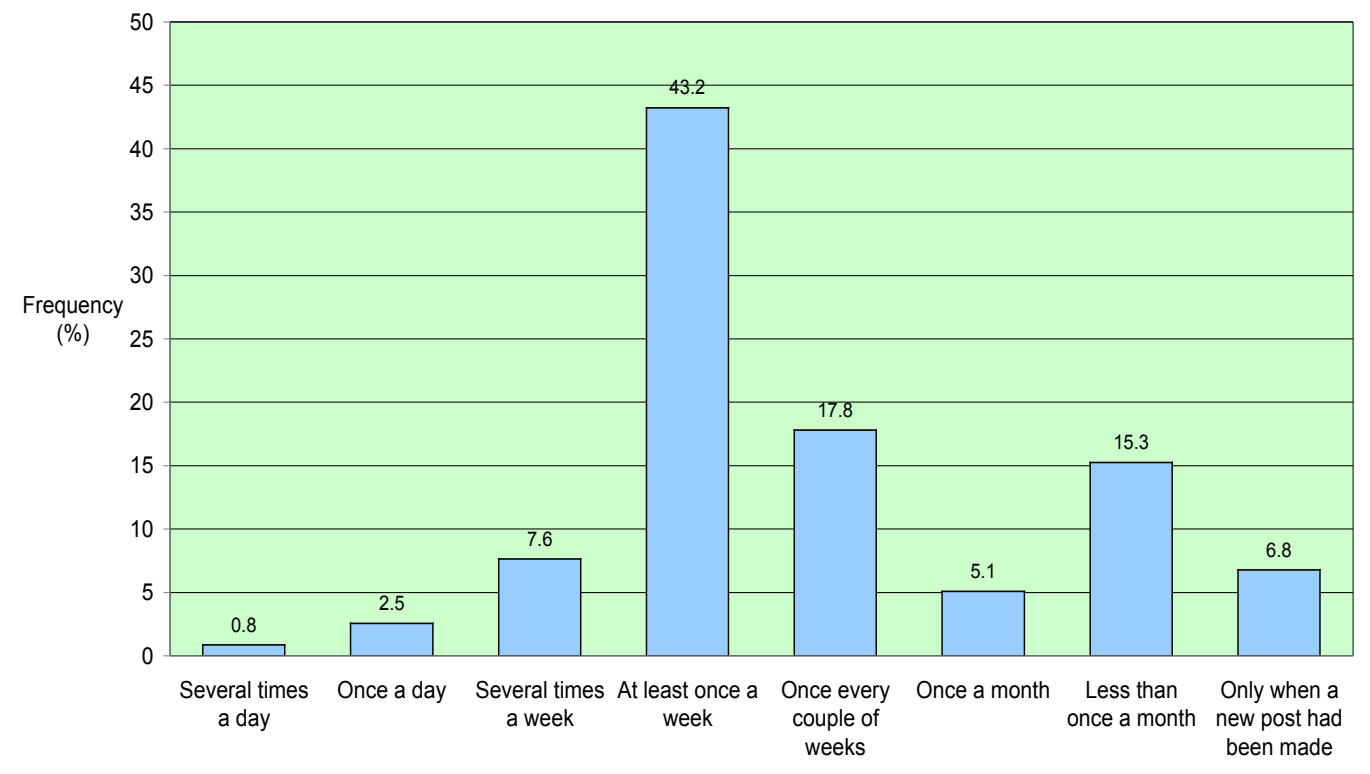

Figure 1: Frequency of student engagement with the course Facebook page $(n=118)$. 
A mixed response was noted regarding the perceived effectiveness of the course Facebook page as a learning tool. Approximately half of the students (51\%) stated that the course Facebook page was an effective learning tool, 37\% claimed it was not effective, and $12 \%$ stated they were unsure. No difference was found between the university course level (undergraduate or postgraduate) and perception of effectiveness as a learning tool $(p>0.05)$.

Commonly stated reasons for the course Facebook page being an effective learning tool included the following:

i. The page enhanced communication and interaction between students and the course instructors.

I found it a good learning resource because most of the questions that people asked on the page were relevant to my study (Undergraduate student, 3rd year course).

ii. Interaction with the Facebook page was easy as students were commonly using Facebook for social networking.

Because I was already on Facebook, the page was a quick and easy way to get information and keep up to date (Undergraduate student, 3rd year course).

iii. Students were able to receive updates and information which may have been missed via other communication means.

I liked it because I was able to gain information that was perhaps missed if I didn't attend class that week." (Undergraduate student, 3rd year course).

iv. Response to questions and facilitation of discussions were faster than relying on email and discussion boards.

It was a faster way of communicating rather than emailing the lecturer all the time (Postgraduate student, 1st year course).

Commonly stated reasons for the course Facebook page not being an effective learning tool included the following:

i. The course Facebook page added to communication channels which students were expected to keep up to date with.

It was just another thing that had to be checked - email, Learning@Griffith, Facebook (Postgraduate student, 1st year course).

ii. Students were frustrated that information was duplicated on the course Facebook page and the Learning@Griffith website.

Everything was repeated on Learning@Griffith so I didn't even check the page (Undergraduate student, 1st year course).

iii. Students did not receive a Facebook 'notification' when information was posted (due to the use of a Facebook 'Page', not a 'Group').

I forgot it existed as I wasn't notified when new posts were made (Postgraduate student, 1st year course). 
Despite a mixed response regarding the use of the course Facebook page as a learning tool, the majority of students $(n=110,76.4 \%)$ recommended the use of a Facebook page for future courses. Commonly stated recommendations for improvement to the course Facebook page included:

i. The course Facebook page is recommended to be developed into a 'Group'. Each member of the group is then sent a notification when information has been posted.

Make it a group because when someone comments, it then comes up as a notification. It doesn't do that with a page (Postgraduate student, 1st year course).

ii. The instructor should respond to all questions posted by students, even when the question has been attempted to be answered by fellow classmates.

When questions from students were posted, I would have liked to have seen the answer from the lecturer as well as other students. Sometimes these were delayed or not given at all (Undergraduate student, 3rd year course).

iii. Increased interaction by students will facilitate learning and collaboration amongst peers.

It would have been better if more students were active on the page (Undergraduate student, 1st year course).

\section{Discussion}

The purpose of this investigation was to examine the use of course-specific 'Facebook pages' that had been integrated into several university courses, and evaluate its efficacy as a course learning tool using student perceptions. The findings from this study indicate that Facebook may be an appropriate addition to traditional e-learning tools, providing an integration of technology that is well received and used by today's students with an application that can be adapted to deliver content in a similar way to conventional learning management systems.

Facebook is an application familiar to most university students and in this study, nearly all of the students already had an active Facebook account. Similarly high rates of Facebook use by university students have been observed previously (Ophus \& Abbitt, 2009; Roblyer et al., 2010; Wise et al., 2011). This level of access indicates that Facebook is well accepted by students and offers an opportunity for educators to provide students with information using an application they are familiar with. In addition, students appear to be receptive to using Facebook for educational purposes. The students in this study anticipated learning benefits by increased interaction and participation in discussions, as well as notifications of course related information.

Ophus \& Abbitt (2009) reported comparable data, indicating that students were largely supportive of using a social networking system in their higher education courses. Likewise, McCarthy (2012) reported supportive attitudes from students for the use of Facebook as an academic tool, highlighting responses indicating Facebook is a platform familiar to students and allows access to academic information on a system that they are constantly engaged with. Wise et al. (2011) argued that Facebook has only a limited role to play in promoting student engagement, and that institutional based learning management systems can replicate many of the interactive functions of Facebook. However, results from the present study and that of McCarthy (2012) indicate that 
students liked that they could receive academic information on Facebook, because it was something they were accessing frequently and didn't have to log in to an additional university based web page to receive that information. Institution based learning management systems often require students to navigate to the university website, insert a password and then navigate to the correct course page before being able to receive announcements or information. Students may see this process as cumbersome and problematic. Facebook on the other hand, appears to be a site that students are interacting with frequently, particularly given that applications are available for tablet and smart phone devices. This provides a convenient environment in which academic information can be integrated into a space that students are already using.

Acceptance of incorporating Facebook into university courses was highlighted by the number of students who accessed and engaged with the course pages. In this study, the majority of students engaged with the course Facebook page at some stage throughout the semester. However, a mixed response was received from students regarding the effectiveness of the Facebook page as a learning tool. Only half of the students indicated that having a course Facebook page was effective for their learning. This may have been due to the use of a Facebook 'page' opposed to that of a Facebook 'group', with many students commenting that they weren't notified via their personal profiles when new announcements were made on the course page. It may also be a reflection of the different approaches taken by instructors when integrating this technology into the course. Generally the instructors were interested in the use of the technology to augment student learning, however, at times they had difficulty maintaining momentum with Facebook page activities that had been initiated. Changing the way Facebook is used as a course learning tool may facilitate greater student engagement and appreciation for its integration into university education. The need to adjust the strategy (e.g. using a 'group' instead of a 'page') highlights the importance of understanding how students use this technology, so that it is beneficial rather than counter-productive.

Despite the mixed response regarding its effectiveness, the majority of students recommended using Facebook for their future courses. While Facebook may not aid students' learning specifically, it lends itself to the provision of productive pedagogy. One of the critical components to instructive strategies is active student participation, with collaboration and co-operation foremost to successful learning (Ferdig, 2007). There is some evidence suggesting technology can support these interactions (Denning \& Smith, 1997), and Facebook is a popular platform by which this can be conveyed. A high rate of student engagement with the course Facebook page in this study suggests that this technology could promote a collaborative and cooperative learning environment. Continued integration of Facebook into courses may see further benefits through enhanced 'student to student' and 'student to instructor' communication, which in turn may translate to greater learning outcomes. Further research is required to specifically understand if and how the use of Facebook can enhance student learning outcomes.

University educators may benefit from recognising the inherent value in blending the best of traditional learning experiences with those enhanced by emerging technologies such as Facebook. Using this technology allows content to be more accessible and flexible for students, which may enhance the quality of student learning. It is important for educators to embrace the latest technology and discover ways to harness student engagement for activities that work in conjunction with, not against, their 
pedagogical philosophies and learning goals (Ferdig, 2007). Facebook is one platform that may assist educators in promoting student learning. One of the challenges however, is finding ways to integrate this technology into curriculum design and assessment as the boundaries are pushed looking for new ways to engage students in meaningful and intellectually stimulated learning.

The current study evaluated students' perceptions of using a designated Facebook page as a learning resource in university courses. The approach used in this study will be continued in future offerings of these courses and will allow additional research and evaluation to be conducted. Future research should employ methods that assess the ability of Facebook to assist in the development of competencies and learning outcomes when integrated into course resources. In addition, a comparison between traditional learning management systems and equivalent Facebook functions should be conducted in order to determine the most efficient and convenient platform for student engagement and learning.

\section{Conclusion}

Facebook is well used by students at university and may be an excellent tool to integrate into the learning resources of university courses. The findings from this study indicate that students are receptive to incorporating Facebook into their academic lives and perceive benefits through enhanced communication, interaction, and flexibility in course content delivery. While the technology is well received, it is still unclear if and how Facebook can enhance student learning outcomes. Continued investigation of Facebook use in university education may provide further insight into these matters.

\section{References}

Bosch, T. E. (2009). Using online social networking for teaching and learning: Facebook use at the University of Cape Town. Communicatio: South African Journal for Communication Theory and Research, 35(2), 185-200. http:/ / dx.doi.org/10.1080/02500160903250648

Boyd, D. M. \& Ellison, N. B. (2007). Social network sites: Definition, history, and scholarship. Journal of Computer-Mediated Communication, 13(1), 210-230. http: / / dx.doi.org/10.1111/j.1083-6101.2007.00393.x

Cluett, L. (2010). Online social networking for outreach, engagement and community: The UWA Students' Facebook page. In Educating for sustainability. Proceedings of the 19th Annual Teaching Learning Forum, 28-29 January 2010, Perth: Edith Cowan University. http: / / otl.curtin.edu.au/tlf/tlf2010/ refereed/cluett.html

Coates, H., James, R. \& Baldwin, G. (2005). A critical examination of the effects of learning management systems on university teaching and learning. Tertiary Education and Management, 11(1), 19-36. http: / / dx.doi.org/10.1080/13583883.2005.9967137

Dalsgaard, C. (2006). Social software: E-learning beyond learning management systems. European Journal of Open and Distance Learning, 2006(II). http: / / www.eurodl.org/materials / contrib / 2006/Christian_Dalsgaard.htm

Denning, R. \& Smith, P. (1997). Cooperative learning and technology. Journal of Computers in Mathematics and Science Teaching, 16(2), 177-200. http: / / www.editlib.org/p/20941

Elliott, K. M. \& Shin, D. (2002). Student satisfaction: An alternative approach to assessing this important concept. Journal of Higher Education Policy and Management, 24(2), 197-209. http: / / dx.doi.org/10.1080/1360080022000013518 
Ferdig, R. E. (2007). Editorial: Examining social software in teacher education. Journal of Technology and Teacher Education, 15(1), 5-10. http:/ / www.editlib.org/p/23518

Hewitt, A. \& Forte, A. (2006). Crossing boundaries: Identity management and student/faculty relationships on the Facebook. In Computer Supported Cooperative Work Conference, Banff, Alberta, Canada. [verified 15 Aug 2012]

http: / / citeseerx.ist.psu.edu / viewdoc/download?doi=10.1.1.94.8152\&rep=rep1\&type=pdf

Kabre, F. \& Brown, U. J. (2011). The influence of Facebook usage on the academic performance and the quality of life of college students. Journal of Media \& Communication Studies, 3(4), 144150. http:/ / www.academicjournals.org/JMCS/PDF/pdf2011/April/Kabre\%20and\%20Brown.pdf

Kirschner, P. A. \& Karpinski, A. C. (2010). Facebook and academic performance. Computers in Human Behavior, 26(6), 1237-1245. http:/ / dx.doi.org/10.1016/j.chb.2010.03.024

Madge, C., Meek, J., Wellens, J. \& Hooley, T. (2009). Facebook, social integration and informal learning at university: 'It is more for socialising and talking to friends about work than for actually doing work'. Learning, Media and Technology, 34(2), 141-155. http: / / dx.doi.org/10.1080/17439880902923606

Mazman, S. G. \& Usluel, Y. K. (2010). Modeling educational usage of Facebook. Computers $\mathcal{E}$ Education, 55(2), 444-453. http: / / dx.doi.org/10.1016/j.compedu.2010.02.008

McCarthy, J. (2010). Blended learning environments: Using social networking sites to enhance the first year experience. Australasian Journal of Educational Technology, 26(6), 729-740. http: / / www.ascilite.org.au/ajet/ajet26/mccarthy.html

McCarthy, J. (2012 ). International design collaboration and mentoring for tertiary students through Facebook. Australasian Journal of Educational Technology, 28(5), 755-775. http:// www.ascilite.org.au/ajet/ajet28/mccarthy.html

Naidu, S. (2005). Learning \& teaching with technology: Principles and practices. Oxon, UK: Routledge Falmer.

Ophus, J. D. \& Abbitt, J. T. (2009). Exploring the potential perceptions of social networking systems in university courses. MERLOT Journal of Online Learning and Teaching, 5(4), 639-648. http: / / jolt.merlot.org/vol5no4/ophus_1209.pdf

Oradini, F. \& Saunders, G. (2008). The use of social networking by students and staff in higher education. Paper presented at the iLearning Forum, Paris. http: / / www.eifel.org/ publications / proceedings / ilf08/ contributions / improving-quality-of-learning-withtechnologies/Oradini_Saunders.pdf

Ouf, S., Nasr, M. \& Helmy, Y. (2010). An enhanced e-learning ecosystem based on an integration between cloud computing and Web 2.0. In IEEE International Symposium on Signal Processing and Information Technology (ISSPIT), 2010, Helwan, Egypt.

http: / / ieeexplore.ieee.org/stamp/ stamp.jsp?tp=\&arnumber=5711721

Rambe, P. (2012). Critical discourse analysis of collaborative engagement in Facebook postings. Australasian Journal of Educational Technology, 28(2), 295-314.

http: / / www.ascilite.org.au/ajet/ajet28/rambe.html

Roblyer, M. D., McDaniel, M., Webb, M., Herman, J. \& Witty, J. V. (2010). Findings on Facebook in higher education: A comparison of college faculty and student uses and perceptions of social networking sites. The Internet and Higher Education, 13(3), 134-140.

http: / / dx.doi.org/10.1016/j.iheduc.2010.03.002 
Santos, I., Hammond, M., Durli, Z. \& Chou, S. (2009). Is there a role for social networking sites in education? In A. Tatnall \& A. Jones (Eds.), Education and Technology for a Better World (Vol. 302, pp. 321-330): Springer Boston. http:/ / dx.doi.org/10.1007/978-3-642-03115-1_34

SPSS (2010). Statistical Packages for the Social Sciences 19.0 for Windows. Chicago, IL: SPSS, Inc.

Subrahmanyam, K., Reich, S., Waechter, N. \& Espinoza, G. (2008). Online and offline social networks: Use of social networking sites by emerging adults. Journal of Applied Developmental Psychology, 29(6), 420-433. http: / / dx.doi.org/10.1016/j.appdev.2008.07.003

Tian, S. W., Yu, A. Y., Vogel, D. \& Kwok, R. C.-W. (2011). The impact of online social networking on learning: A social integration perspective. International Journal of Networking and Virtual Organisations, 8(3/4), 264-280. http:/ / dx.doi.org/10.1504/IJNVO.2011.039999

Willems, J. \& Bateman, D. (2011). The potentials and pitfalls of social networking sites such as Facebook in higher education contexts. In Changing demands, changing directions. Proceedings ascilite Hobart 2011.

http: / / www.ascilite.org.au/conferences/hobart11/ downloads / papers / Willems-poster.pdf

Wise, L. Z., Skues, J. \& Williams, B. (2011). Facebook in higher education promotes social but not academic engagement. In Changing demands, changing directions. Proceedings ascilite Hobart 2011. http: / / www.ascilite.org.au / conferences / hobart11/ downloads / papers / Wise-full.pdf

Wolfe, A. M. (2007). Student attitudes towards social networks and learning modalities. In Proceedings of the Marketing Management Association (MMA) Spring Conference, Chicago, Illinois, USA. http: / / alisonwolfe.com/ wordpress/wpcontent/uploads/Student_Attitudes_Social_Networks2.pdf

Authors: Mr Christopher Irwin, PhD candidate, School of Public Health, Griffith Health Institute, Griffith University, Gold Coast, Queensland 4222, Australia. Email: c.irwin@griffith.edu.au

Web: http: / / www.griffith.edu.au/health/school-public-health/staff

Miss Lauren Ball, Associate Lecturer, School of Public Health, Griffith Health Institute, Griffith University, Gold Coast, Queensland 4222, Australia.

Email: lauren.ball@griffithuni.edu.au

Web: http: / / www.griffith.edu.au/health/school-public-health/staff/lauren-ball

Dr Ben Desbrow, Senior Lecturer, School of Public Health, Griffith Health Institute, Griffith University, Gold Coast, Queensland 4222, Australia.

Email: b.desbrow@griffith.edu.au

Web: http: / / www.griffith.edu.au/health/school-public-health/staff/dr-ben-desbrow

Dr Michael Leveritt, Senior Lecturer, School of Human Movement Studies,

The University of Queensland, Brisbane, Queensland 4072, Australia.

Email: michael.leveritt@uq.edu.au

Web: http: / / www.hms.uq.edu.au / our-staff/ academic-staff/ michael-leveritt,-phd.asp

Please cite as: Irwin, C., Ball, L., Desbrow, B. \& Leveritt, M. (2012). Students'

perceptions of using Facebook as an interactive learning resource at university.

Australasian Journal of Educational Technology, 28(7), 1221-1232.

http: / / www.ascilite.org.au/ajet/ajet28/irwin.html 